\title{
Study of the Immunological Status of Iraqi Vitiligo Patients
}

\author{
Shatha F. Tariq \\ Talib A. Hussein \\ Department of Biology, College of Science for Women, University of Baghdad \\ Received 25/5 /2015 \\ Accepted 8/ 9/2015 \\ (c) (i) (9) \\ This work is licensed under a Creative Commons Attribution-NonCommercial- \\ NoDerivatives 4.0 International Licens
}

\begin{abstract}
:
Vitiligo is an acquired idiopathic skin disorder characterized by depigmented macules due to loss of cutaneous melanocytes. A potential role of the immune dysfunction has been suggested in vitiligo, so to test this hypothesis, certain cytokines (IL-17A and TNF- $\alpha$ ) and immunoglobulins (IgM, IgG, IgA and total IgE) were investigated in all participants. The study included: 60 patients with age range between (6-55) year; 30(11 males and 19 females) were untreated and 30(12 males and 18 females) were treated with Narrow Band Ultraviolet-B (NB-UVB) and 30 (14 males and 16 females) apparently healthy control. Serum was separated and cytokines (IL-17A and TNF- $\alpha$ ) and total immunoglobulin E (IgE) were detected by using Enzyme Linked Immunosorbent Assay (ELISA); while immunoglobulins (IgM, IgG and IgA) were detected by using Single Radial Immunodiffusion (SRID) method. The results showed that the mean levels of serum IL-17A and TNF- $\alpha$ in both untreated and NB-UVB treated vitiligo patients were increased significantly $(\mathrm{p} \leq 0.05)$ as compared with healthy control. The mean levels of serum $\operatorname{IgG}$ and $\operatorname{IgA}$ in untreated vitiligo patients showed non significant decreased $(\mathrm{P}>0.05)$ as compared to healthy control; while serum IgM and IgE levels were found to be increased, but the increase was statistically non significant $(\mathrm{P}>0.05)$. The mean levels of serum $\operatorname{IgM}$ and $\mathrm{IgG}$ in NB-UVB treated vitiligo patients showed a significant increased $(p \leq 0.05)$ as compared to both untreated vitiligo patients and healthy control, while serum IgA level found to be increased, but the increase was statistically non significant $(\mathrm{P}>0.05)$ as compared to untreated vitiligo patients. From these findings we can conclude that marked high serum levels of IL-17A and TNF- $\alpha$ in vitiligo patients clarify their important participation in the pathogenesis of vitiligo, also the alteration in the mean levels of serum immunoglobulins indicate the role of humoral immunity in vitiligo patients. Among the treatment options available in vitiligo, phototherapy especially NB-UVB was one of the safest and most effective especially in patients with generalized vitiligo.
\end{abstract}

Key words: Vitiligo, IL-17A, TNF- $\alpha$, Immunoglobulins.

\section{Introduction:}

Vitiligo is a commonly idiopathic, acquired or inherited depigmentary disorder, in which the destruction of functioning melanocytes causes depigmentation of the skin, hair and mucosal surfaces [1]. It characterized by asymptomatic, well circumscribed, milky or chalky white macules or 
patches [2]. Large population surveys have shown a worldwide prevalence of 1-2 \% [3].In Iraq, the prevalence of dermatoses has risen from $33.5 \%$ in 1987 [4] to $40.9 \%$ in 2010 [5].Pigmentary disorders were the third ranking dermatosis in Baghdad governorate, 118 cases $(17.8 \%)$ out of 663 ; vitiligo was the most common in $8.3 \%$ of patients[6].The disease occurs independently of age and race; both sexes are equally affected [7].

The course of the disease is usually unpredictable; however it is often slowly progressive. In some patients the lesions may remain static, at other times vitiligo may progress rapidly [8].Vitiligo characterized by the reduction of the melanocytes until their complete loss and by the disappearance of the melanin granules in the basal and spinous layer keratinocytes [9]. Vitiligo can be classified into three broad categories primarily based on the distribution of lesions: localized, generalized, and universal vitiligo[10].Evidence indicated that large number of vitiligo patients claim that the disease appeared or spread from one tiny patch to a wide pattern, after severe physical and /or mental stress. These are called precipitating factors, because they are not the cause of the disease, but induce its development [11]. There are many theories to explain the etiology, but the most favorable one is the autoimmune reaction which is supported by the following observations: the disease might associated with other autoimmune diseases, the presence of circulating auto-antibodies, and the histopathological findings which are the lymphocytic infiltration of the epidermis and alteration in cytotoxic $\mathrm{T}$ cells (CD8+) and helper T cells (CD4+) [12], in addition many studies have showed the role of both cellular and humoral immunity in the pathogenesis of vitiligo, as cytokines are important mediators of immunity there are evidences suggest that they participate in the pathogenesis of vitiligo [13], so to identify the relationship between immunological function and vitiligo; level of cytokines (IL-17A and TNF- $\alpha$ ) and immunoglobulins ( $\operatorname{IgM}, \operatorname{IgG}, \operatorname{Ig} \mathrm{A}$ and total $\operatorname{IgE}$ ) were measured in the sera of the three investigated groups.

\section{Materials and Methods:}

This study was carried out at the Department of Dermatology and Venereology in both Al-Yarmouk and Baghdad Teaching Hospitals during the period from November 2014 to April 2015. The study included 60 vitiligo patients; their ages ranged from (6-55) years. The diagnosis was made by the consultant medical staff at the clinic on the basis of international criteria. The current study included three investigated groups: 30 untreated vitiligo patients (11 males and 19 females),30 vitiligo patients treated with NB-UVB two times a week for (4-10) weeks (12 males and 18 females) and 30 apparently healthy control (14 males and 16 females), who were matched patients by age (9-53) years.

The blood samples were collected (5) $\mathrm{ml}$ from the venous blood of the patients of both groups and control group then they were transferred to plain tubes and left for around an hour to clot at room temperature. Then, they were separated by centrifugation at speed (2500) round per minute for (10) minutes to collect the serum by using micropipette. Later, the separated serum was divided into 6 aliquots (150) $\mu 1$ in Eppendorf tubes and kept at $-20^{\circ} \mathrm{C}$ until use in immunological assay. The level of cytokines (IL-17A and TNF- $\alpha$ ) and total IgE were detected by using Enzyme Linked Immunosorbent Assay (ELISA) technique kits; while immunoglobulins (IgM, IgG and $\operatorname{IgA}$ ) were detected by using Single Radial Immunodiffusion (SRID) method.

Data were entered and analyzed by using SPSS (Statistical Package for Social 
Sciences) version 20 for Windows. Descriptive statistics (frequencies, percentages, tables and graphs) were used. Data were presented in terms of mean \pm Standard Error (S.E.), and differences between means were assessed by one way ANOVA test. The difference was considered significant when the probability $(\mathrm{P})$ value was $\leq$ $0.05[14]$.

\section{Results:}

Out of 60 patients in this study, 23 $(38.33 \%)$ patients were males and 37 $(61.67 \%)$ patients with a ratio $\mathrm{F} / \mathrm{M}$ equals to 1.6:1. Regarding patients group, the mean age was (28.55) years, young individuals appeared to be more susceptible to infected by vitiligo; especially when their age group was (1120) year with a percentage at (36.67) (Table 1).

In the current study 23 (38.33\%) of patients had a positive family history of vitiligo .First-degree relatives were affected in 17 (28.33\%), second-degree relatives in $5(8.33 \%)$ and third- degree relatives in $1(1.67 \%)$ (Table 2$)$.

Table (1): Distribution and percentage of vitiligo patients according to age groups.

\begin{tabular}{|l|l|l|}
\hline \multirow{2}{*}{$\begin{array}{l}\text { Age at Onset } \\
\text { (years) }\end{array}$} & Patients \\
\cline { 2 - 3 } Less than 10 & No. & $\%$ \\
\hline $11-20$ & 22 & 26.67 \\
\hline $21-30$ & 10 & 36.67 \\
\hline $31-40$ & 5 & 16.67 \\
\hline More than 41 & 7 & 8.33 \\
\hline
\end{tabular}

Table (2): Distribution and percentage of vitiligo patients according to family history.

\begin{tabular}{|c|c|c|c|}
\hline Family History & $\begin{array}{l}\text { No. } \\
(\%)\end{array}$ & $\begin{array}{l}\text { Degree of } \\
\text { Relatives }\end{array}$ & $\begin{array}{l}\text { No. } \\
(\%)\end{array}$ \\
\hline \multirow{3}{*}{$\begin{array}{c}\text { Positive Family } \\
\text { History }\end{array}$} & \multirow{3}{*}{$\begin{array}{c}23 \\
(38.33)\end{array}$} & $1^{\text {st }}$ Degree & $17(28.33)$ \\
\hline & & $2^{\text {nd }}$ Degree & $5 \quad(8.33)$ \\
\hline & & $3^{\text {rd }}$ Degree & $\begin{array}{ll}1 & (1.67) \\
\end{array}$ \\
\hline $\begin{array}{c}\text { Negative Family } \\
\text { History }\end{array}$ & $\begin{array}{c}37 \\
(61.67)\end{array}$ & & \\
\hline
\end{tabular}

Serum Level of Interleukin-17A and Tumor Necrosis Factor-alpha:

Results of this study showed significant differences $(p \leq 0.05)$ in the mean level of IL-17A in the sera of the three investigated groups. It was noticed that serum level of IL-17A in both untreated and NB-UVB treated vitiligo patients $(188.62 \pm 4.83$ and $174.03 \pm$ $5.46) \mathrm{pg} / \mathrm{ml}$ respectively were increased as compared with healthy control $(116.07 \pm 4.41) \mathrm{pg} / \mathrm{ml}$ (Table 3).The mean level of TNF- $\alpha$ in both untreated and NB-UVB treated vitiligo patients $(64.68 \pm 1.12$ and $61.94 \pm 1.85) \mathrm{pg} / \mathrm{ml}$ respectively increased significantly $(\mathrm{p} \leq$ 0.05 ) as compared with healthy control $(50.64 \pm 1.91) \mathrm{pg} / \mathrm{ml}$,but showed non significant differences $(\mathrm{p}>0.05)$ as compared with each other (Table 3 ).

\section{Serum Level of Immunoglobulins IgM, IgG, IgA and Total IgE:}

Untreated vitiligo patients showed non significant increased $(\mathrm{p}>0.05)$ in the mean level of $\operatorname{IgM}(121.85 \pm 10.7) \mathrm{mg} / \mathrm{dl}$ as compared with healthy control $(111.5 \pm 6.91) \mathrm{mg} / \mathrm{dl}$. However the mean level of IgM in NB-UVB treated vitiligo patients $(167.69 \pm 3.23) \mathrm{mg} / \mathrm{dl}$ showed a significant increased $(\mathrm{p} \leq 0.05)$ as compared with the mean levels of both untreated vitiligo patients and healthy control (121.85 \pm 10.7 and $111.5 \pm 6.9)$ $\mathrm{mg} / \mathrm{dl}$ respectively (Table 4$)$.

Untreated vitiligo patients showed non significant decreased $(p>0.05)$ in the mean level of $\operatorname{IgG}(1045.24 \pm$ 46.92) $\mathrm{mg} / \mathrm{dl}$ as compared with healthy control $(1082.02 \pm 37.99) \mathrm{mg} / \mathrm{dl}$.However the mean level of IgG in NB-UVB treated vitiligo patients $(1228.38 \pm 43.75) \mathrm{mg} / \mathrm{d}$ showed a significant increased $(\mathrm{p} \leq 0.05)$ as compared with the mean levels of both untreated vitiligo patients and healthy control (1045.24 \pm 46.92 and $1082.02 \pm 37.99) \mathrm{mg} / \mathrm{dl}$ respectively (Table4).

The mean level of $\operatorname{IgA}$ showed non significant differences $(\mathrm{P}>0.05)$ between 
healthy control group $(239.38 \pm 19.69)$ $\mathrm{mg} / \mathrm{dl}$ and both untreated and NB-UVB treated vitiligo patients $(216.4 \pm 18.79$ and $233.84 \pm 18.88) \mathrm{mg} / \mathrm{dl}$ respectively .Furthermore we can notice that the mean level of $\operatorname{Ig} \mathrm{A}$ in untreated vitiligo patients $(216.4 \pm 18.79) \mathrm{mg} / \mathrm{dl}$ was slightly decreased as compared with the mean levels of both NB-UVB treated vitiligo patients and healthy control (233.84 18.88 and $239.38 \pm 19.69)$ $\mathrm{mg} / \mathrm{dl}$ respectively(Table 4$)$.

The mean levels of IgE showed no significant differences $(\mathrm{P}>0.05)$ among the three investigated groups. We can notice that the mean levels of IgE in both untreated and NB-UVB treated vitiligo patients $(147.01 \pm 6.67,144.67 \pm 5.09)$ $\mathrm{IU} / \mathrm{ml}$ respectively showed non significant increased as compared with healthy control $(134.89 \pm 5.67) \mathrm{IU} / \mathrm{ml}$ (Table 4).

Table (3): Mean serum level of IL-17A and TNF- $\alpha(\mathrm{pg} / \mathrm{ml})$ in the study samples.

\begin{tabular}{|c|c|c|c|}
\hline Samples & No. & $\begin{array}{l}\text { Mean } \pm \text { S.E. } \\
\text { IL-17A } \\
(\mathbf{p g} / \mathrm{ml})\end{array}$ & $\begin{array}{c}\text { Mean } \pm \text { S.E. } \\
\text { TNF- } \alpha \\
(\text { pg/ml })\end{array}$ \\
\hline $\begin{array}{c}\text { Untreated Vitiligo } \\
\text { Patients }\end{array}$ & 30 & $\begin{array}{c}188.62 \pm \\
4.83^{\mathrm{a}}\end{array}$ & $64.68 \pm 1.12^{a}$ \\
\hline $\begin{array}{c}\text { NB-UVB Treated } \\
\text { Vitiligo Patients }\end{array}$ & 30 & $\begin{array}{c}174.03 \pm \\
5.46^{\mathrm{b}}\end{array}$ & $61.94 \pm 1.85^{\mathrm{a}}$ \\
\hline Healthy Control & 30 & $\begin{array}{c}116.07 \pm \\
4.41^{c}\end{array}$ & $50.64 \pm 1.91^{b}$ \\
\hline \multicolumn{2}{|l|}{ LSD } & 11.12 & 3.92 \\
\hline \multicolumn{4}{|c|}{$\begin{aligned} * \text { Different letters }=\text { Significant difference }(P \leq 0.05) & \text { between means. } \\
* \text { Similar letters }= & \begin{array}{l}\text { No significant difference }(P>0.05) \\
\text { between means. }\end{array}\end{aligned}$} \\
\hline
\end{tabular}

Table (4): Mean serum level of IgM, IgG, IgA (mg/dl) and total IgE (IU/ml) in the study samples.

\begin{tabular}{|c|c|c|c|c|c|}
\hline Samples & No & $\begin{array}{c}\text { Mean } \\
\pm \text { S.E. } \\
\operatorname{IgM}(\mathrm{mg} / \mathrm{dl})\end{array}$ & $\begin{array}{l}\text { Mean } \pm \text { S.E. } \\
\operatorname{IgG(mg/dl)}\end{array}$ & $\begin{array}{c}\text { Mean } \\
\pm \text { S.E. } \\
\text { IgA(mg/dl) }\end{array}$ & $\begin{array}{c}\text { Mean } \\
\pm \text { S.E. } \\
\text { IgE(IU/d) }\end{array}$ \\
\hline $\begin{array}{c}\text { Untreated } \\
\text { Vitiligo } \\
\text { Patients }\end{array}$ & 30 & $\begin{array}{l}121.85 \pm \\
10.70^{\mathrm{a}}\end{array}$ & $\begin{array}{c}1045.24 \\
46.92^{\mathrm{a}}\end{array}$ & $\begin{array}{r}216.40 \pm \\
18.79^{\mathrm{a}}\end{array}$ & $\begin{array}{c}147.01 \pm \\
6.67^{\mathrm{a}}\end{array}$ \\
\hline $\begin{array}{c}\text { NB-UVB } \\
\text { Treated } \\
\text { Vitiligo } \\
\text { Patients }\end{array}$ & 30 & $\begin{array}{c}167.69 \pm \\
3.23^{\mathrm{b}}\end{array}$ & $\begin{array}{c}1228.38 \\
43.75^{\mathrm{b}}\end{array}$ & $\begin{array}{c}233.84 \pm \\
18.88^{\mathrm{a}}\end{array}$ & $\begin{array}{l}144.67 \pm \\
5.09^{\mathrm{a}}\end{array}$ \\
\hline $\begin{array}{l}\text { Healthy } \\
\text { Control }\end{array}$ & 30 & $\begin{array}{c}111.50 \pm \\
6.91^{\mathrm{a}}\end{array}$ & $\begin{array}{c}1082.02 \pm \\
37.99^{\mathrm{a}}\end{array}$ & $\begin{array}{c}239.38 \pm \\
19.69^{\mathrm{a}}\end{array}$ & $\begin{array}{c}134.89 \pm \\
5.67^{\mathrm{a}}\end{array}$ \\
\hline \multicolumn{2}{|l|}{ LSD } & 17.8 & $\begin{array}{l}101.1 \\
\end{array}$ & $\begin{array}{l}44.98 \\
\end{array}$ & 13.6 \\
\hline
\end{tabular}

\section{Discussion:}

Vitiligo is an acquired idiopathic pigmentary skin disorder, despite the fact that vitiligo affects both sexes equally, the distribution by gender in this study showed that there were more females than males .These differences can be explained by the fact that women are more affected by aesthetic problems due to the greater psycho-social perceived impact of the disease and so for the sake of healing they are looking more and more likely to compelling treatment.

The mean age of vitiligo patients in this study was (28.55) year .This finding was in agreement with Nejad et al. [15] who reported that the mean age of vitiligo patients was (28.11) year. In contrast Sharquie [16] reported that the mean age of Iraqi vitiligo patients was 17.9 year. Results of this study showed that the higher distribution of vitiligo patients occurred between (11-20) year age group. This finding was in agreement with Sehgal and Srivastava [17] who mentioned that vitiligo occurs in young people between the age of (1020) year. The preponderance of young individuals in the current study may be due to the fact that many of them had a positive family history especially in the first-degree relatives (parents, brothers and sisters). This indicated that vitiligo had a genetic factor and predominantly affects a younger population and as the condition has a major cosmetic concern therefore early diagnosis and treatment is essential [18].

Results of this study showed that majority of vitiligo cases are sporadic without a family history of the disease. However, Familial cases of vitiligo are common, suggesting a genetic basis for this disorder. About $15-20 \%$ of patients report at least one affected first-degree relative [19]. Furthermore, among Caucasians, the risk of vitiligo developing in a patient's sibling is approximately $6.1 \%$ an increase of 16 - 
fold compared to the general Caucasian population where the prevalence of the disease is $0.38 \%$ [20]. In Iraq, it was found that $25 \%$ of patients had a positive family history [16].

The involvement of Th17 cells in vitiligo pathogenesis has been investigated. Several studies came in agreement with the present results, Bassiouny and Shaker [20] and Khan et al. [21], reported a significant elevated level of IL-17A in vitiligo patients when compared with healthy control .It is tempting to speculate that Th17 cells and Tregs exist in a balance such that in the absence of Tregs, Th17 activity amplifies inflammatory cascades which involved skin of patients with vitiligo[22],so the elevated level of IL$17 \mathrm{~A}$ found in this study supported the hypothesis that shifting of the immune system toward Th1 or Th17 and away from Tregs and Th2 may be responsible for development of vitiligo. Interleukin$17 \mathrm{~A}$ is able to induce the release of proinflammatory cytokines such as IL-1, IL-6, TNF $\alpha$, TGF $\beta$, Granulocyte Macrophage Colony-Stimulating Factor (GM- CSF), and prostaglandins from activated immune cells such as fibroblasts, keratinocytes, endothelial cells, and macrophages. These cytokines recruit and activate lymphocytes or neutrophils, which are involved in vitiligo pathogenesis and may cause further inhibition of melanocyte proliferation[23].In vitro human cultured melanocytes treated with IL-17A displayed a reduced melanin production. This study indicated that serum level of TNF- $\alpha$ in both untreated and NB-UVB treated vitiligo patients was increased significantly as compared to healthy control. This finding was in agreement with Laddha et al. [24], but disagreement with the finding of $\mathrm{Yu}$ et al.[25] who reported a significant decrease in TNF- $\alpha$ level in vitiligo patients .Tumor Necrosis Factor- $\alpha$, in addition to being cytotoxic for certain tumor cells, has been confirmed as a multifunctional cytokine that is involved in innate and adaptive immunity. Increased level of TNF- $\alpha$ can alter melanocytes functions, including proliferation, differentiation and immunologic susceptibility to cytotoxicity [26]. Adhesion molecules such as Intercellular Adhesion Molecule1(ICAM-1) are expressed in melanocytes from vitiligo lesions, TNF$\alpha$ is a strong inducer of ICAM-1 in both normal and vitiliginous cultured melanocytes; this pathway could influence melanocyte target recognition by $T$ cells and mediate immunologic cytotoxic damage. Tumor Necrosis Factor- $\alpha$ can inhibit melanogenesis by decreasing the intracellular levels of tyrosinase and tyrosinase-related protein1[27].In addition keratinocytes are involved in melanocyte homeostasis, so any change in keratinocytes may cause melanocyte dysfunction. High levels of TNF- $\alpha$ may play a role in keratinocyte apoptosis, which leads to less production of melanogenic cytokines and therefore melanocyte loss. So, TNF- $\alpha$ is considered as a complex mediator that regulates melanocyte destruction [28].

In the current study serum levels of IL-17A and TNF- $\alpha$ in NB-UVB treated vitiligo patients was decreased as compared to untreated vitiligo patients, these findings suggest that NB-UVB treatment annihilates the IL-17A and TNF- $\alpha$ secretion but the underlying mechanism of action is not very clear. However, a two step effect of NB-UVB has been suggested but may also occur simultaneously. Firstly, there is a local or systemic immuno-modulation leading to down regulation of immune attack against the melanocytes and subsequent stimulation of melanocytes to migrate to epidermis and synthesize melanin [29].

According to this study, the mean levels of serum $\operatorname{IgG}$ and $\operatorname{IgA}$ in untreated vitiligo patients showed non 
significantly decreased as compared to healthy control, while serum IgM and IgE levels were found to be increased, but the increase was statistically non significant. In addition the mean levels of serum $\operatorname{IgM}$ and $\operatorname{IgG}$ in NB-UVB treated vitiligo patients showed significantly increased as compared to both untreated vitiligo patients and healthy control, while serum IgA level was found to be increased, but the increase was statistically non significant as compared to untreated vitiligo patients. Similar studies were done by Rubaiya et al.[30] and Singh et al.[31], they found that the serum levels of $\operatorname{IgG}$ and IgA in vitiligo patients decreased significantly as compared to healthy control, however the change of IgM was statistically non significant. The means value of IgE in this study showed non significant differences among the three investigated group. However findings of the current study showed disagreement with the finding of Perfetti, et al. [32] who mentioned a higher ratio of atopy $(22 \%)$ in the vitiligo group in comparison to the normal population.

Furthermore, a statistically significant decreased in helper $\mathrm{T}$ cells and helper/suppressor ratios $\left(T_{H} / T_{S}\right)$ in comparison with control subjects had been previously reported [33], which supports the above findings and suggested that aberration in cellmediated immunity may be operative in the pathogenesis of vitiligo. This may also indicate that $\operatorname{IgG}$ anti-melanocyte antibodies could have an important role in this disorder, as they can induce melanocyte damage in vitro either by antibody-dependent complement mediated damage or Antibody Dependent Cell Mediated Cytotoxicity (ADCC).

The immunoglobulins level reported in the current study as well as those reported by Rubaiya et al.[30] and Singh et al.[31] studies do indicate the role of humoral immunity in vitiligo patients. B cells are responsible for the production of Ig: however, the amount and type of antibody secreted depends on the physical interaction between antigen presenting cells, $\mathrm{T}$ cells, and $\mathrm{B}$ cells as well as other factors such as cytokines and chemokines [34].

The contradictory differences in data might be due to geographic location of the subject and control group which also influence the level of $\operatorname{IgE}$ as would the season during which the sample was collected. In addition to the individual response to regional and seasonal allergens. Differences in immunodetection technique may also have the potential to introduce variability.

Current results clearly demonstrated that the use of NB-UVB phototherapy alter the Ig levels which may described the effect of UVB on humoral immunity of vitiligo patients and may reflect the clinical response to the phototherapy.

\section{References:}

[1]Goldsmith, L. A.; Katz, S. I.; Gilchrest, B. A.; Paller, A. S.; Leffell, D. J. and Wolff, k. 2012. Vitiligo. Pages 617-847 in S.A. Birlea, R.A. Spritz and D.A. Norris, editors. Fitzpatrick's Dermatology in General Medicine, $8^{\text {th }}$ Ed. McGraw-Hill, New York, USA.

[2]Sehgal, V. N. 2004. Vitiligo: Textbook of Clinical Dermatology, $4^{\text {th }}$ Ed. Jaypee, New Delhi.99-101.

[3]Boisseau -Garsaud, A. M.; Garsaud, P.; Cales- Quist, D.; Helenon, R.; Queneherve, C. and Claire, R. C. 2000. Epidemiology of vitiligo in the French West Indies (Isle of Martinique). Int J Dermatol, 39(1):1820.

[4]Abdul Hussain, H. M. 1987. Morbidity rates of skin diseases in Baghdad city. Diploma Thesis, University of Baghdad, Iraq. 
[5]Khalifa, K. A.; Al Hadithi, T. S.; Al Lami, F. H. and Al Diwan, J. K. 2010. Prevalence of skin disorders among primary-school children in Baghdad governorate, Iraq. EMHJ,16(2):209-213.

[6]Al-Mendalawi, M. D. and Ibrahim, J. G. 2012. Pattern of dermatoses in Iraqi children. EMHJ, 18(4): 365-371.

[7]Behl, P.N., Aggarwal, A. and Srivastava, G. 2003. Vitiligo. Pages 238-241 in P.N. Behl and G. Srivastava, editors. Practice of Dermatology, $9^{\text {th }}$ Ed. CBS Publishers, New Delhi, India.

[8]Mosher, D. B.; Fitzpatrick, T. B.; Freedberg, I. M. and Ortonne, J. P. 1991. Disorders of pigmentation Pages 945-955 in T.B. Fitzpatrick and I.M. Freedberg, editors. Fitzpatrick's dermatology, $5^{\text {th }}$ Ed. McGraw-Hill, New York, USA.

[9]DeFrancesco, V.; Stinco, G.; Laspina, S.; Elena, M.; Purlangeli, M.; Mariuzz, L. and Patrone, P. 2008. Immunohistochemical study before and after narrow-band (311) UVB treatment in vitiligo.Eur $\mathrm{J}$ dermatol, 18(3):292-

[10] Nordlund, J. J. and Lerner, A. B. 1982. Vitiligo. It is important. Arch Dermatol, 118(1):5-8.

[11] Taieb, A. and Picardo, M. 2010. Vitiligo. Springer Berlin Heidelberg. 26-247.

[12] Sharquie, K. E.; Mehenna, S. H.; Naji, A. A. and Al-Azzawi, H. 2004. Inflammatory changes in vitiligo: Stage I and II depigmentation. Am J Dermatopathol, 26(2): 108-112.

[13] Alkahateeb, A.; Fain, P. R.; Thody, A.; Bennett, D. C. and Spritz, R. A. 2003. Epidemiology of vitiligo and associated autoimmune diseases in Caucasian probands and their families. Pigment Cell Res, 16(3): 208-214.

[14] Statistical Package for Social Sience(SPSS). 2012. Version 20.0 for windows.
[15] Nejad, S. B.; Qadim, H. H.; Nazeman, L.; Fadaii, R. and Goldust, M. 2013. Frequency of autoimmune diseases in those suffering from vitiligo in comparison with normal population. Pak J BiolSci, 16(12): 570-574.

[16] Sharquie, K. E. 1984. Vitiligo. Clin Exp Dermatol, 9(2):117-126.

[17] Sehgal, V. N. and Srivastava, G. 2007. Vitiligo: compendium of clinico-epidemiological features. Indian J Dermatol Venereol Leprol, 73(3): 149-156.

[18]Zayed, M.; Eltahlawy, I.; Fathi, M. and Mashaly, H. 2014. Risk factors of vitiligo among patients attending a Tertiary care Hospital. IPHF, 1(3): 18-21.

[19] Passeron, T. and Ortonne, J. P. 2005. Physiopathology and genetics of vitiligo. J Autoimmun, 25(2):6368.

[20] Bassiouny, D. A. and Shaker, O. 2011. Role of interleukin-17 in the pathogenesis of vitiligo. Clin Exp Dermatol 36(3): 292-297.

[21] Khan, R.; Gupta, S. and Sharma, A. 2012.Circulatory levels of T-cell cytokines (interleukin [IL]-2, IL-4, IL-17, and transforming growth factor-beta) in patients with vitiligo. $\mathbf{J}$ Am Acad Dermatol,66(3):510-511.

[22] Elela, M. A.; Hegazy, R. A.; Fawzy, M. M.; Rashed, L. A. and Rasheed, H. 2013. Interleukin 17, Interleukin 22 and FoxP3 expression in tissue and serum of non-segmental vitiligo: A case-controlled study on eighty-four patients. Eur J Dermatol, 23(3):350355.

[23]Huang, F.; Kao, C. Y.; Wachi, S.; Thai, P.; Ryu, J. and Wu, R. 2007. Requirement for both JAK-mediated PI3K signaling and ACT1/TRAF6 /TAK1-dependent activation by IL17A in enhancing cytokine expression in human . J Immunol, 179(10):65046513. 
[24] Laddha, N. C.; Dwivedi, M. and Begum, R. 2013. Increased tumor necrosis factor (TNF- $\alpha)$ and its promoter polymorphisms correlate with disease progression and higher susceptibility towards vitiligo. PLoS ONE, 20(7):12-16.

[25] Yu, H. S.; Chang, K. L.; Yu, C. L.; Li, H. F.; Wu, M. T. and Wu, C. S. 1997. Alterations in IL-6, IL-8, GMCSF, TNF-alpha, and IFN-gamma release by peripheral mononuclear cells in patients with active vitiligo. $\mathrm{J}$ Invest Dermatol, 108(2):527-529.

[26] Morelli, J. G. and Norris, D. A. 1993. Influence of inflammatory mediators and cytokines on human melanocyte function. $\mathbf{J}$ Invest Dermatol, 100(2):19-22.

[27]Zang, S.; Liu, S.; Yu, N. and Xiang, L. 2011. RNA released from necrotic keratinocytes upregulates intercellular adhesion molecule-1expression in melanocytes. Arch Dermatol Res, 303(10):771-776.

[28] Camara-Lemarroy, C. R. and SalasAlanis, J. C. 2013. The role of Tumor Necrosis Factor- $\alpha$ in the pathogenesis of vitiligo. Am J ClinDermatol, 14(5): 343-350.

[29] Ongenae, K.; Geel, N. V. and Naeyaert, J. M. 2003. Evidence for an autoimmune pathogenesis of vitiligo. Pigment Cell Res, 16(2):90-100.

[30] Rubaiya, A.; Mohammad, S. H.; Azad, M. A.; Ullah, A.; Bari, W.; Islam, S. N.; Sabina, Y. and Hasnat, A. 2010. Immunoglobulin levels of vitiligo patients.Pak J Pharm Sci., 23(1):97-102.

[31] Singh, U., Singh, S. and Pandey, S. S. 2013. Study of serum immunoglobulin levels: complements $\mathrm{C} 3$ and $\mathrm{C} 4$ in vitiligopatients in northern India. Prospects in Bioscience, Springer India. 111-115.

[32] Perfetti, L.; Cespa, M.; Nume, A. and Orecchia, G. 1991.Prevalence of atopy in vitiligo. Dermatologica, 182(4): 218-220.

[33] Mittal, R.; Popli, R.; Jassal, J. and Kumar, D. 1994. Immunological study in vitiligo and contact depigmentation. Indian J Dermatol Venereol Leprol. 60(2):92-94.

[34] Janeway, C. A.; Travers, P.; Walport, M. and Shlomchik, M. J. 2005. The immune system in health and disease, $6^{\text {th }} \mathrm{Ed}$. Garland Science Publishing, New York, USA. 


\author{
دراسة الحالة المناعية في مرضى بهاق عراقيين \\ طالب عبد الله حسين \\ شذى فارس طـارق \\ قسم علوم الحياة ، كلية العلوم للبنات ، جامعة بغداد
}

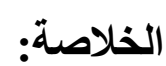

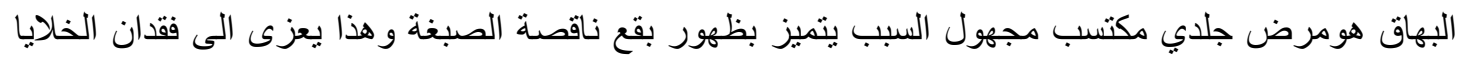

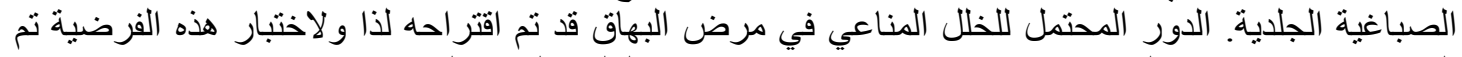

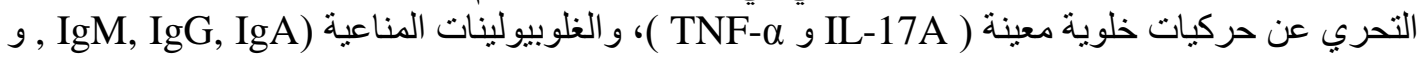

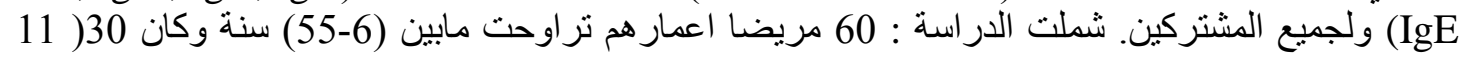

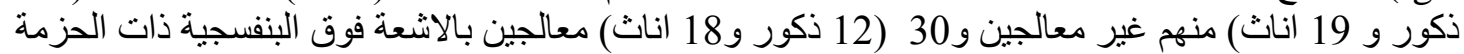

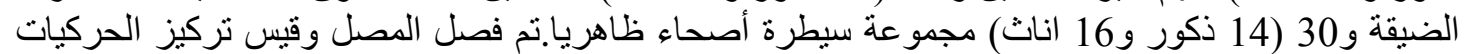

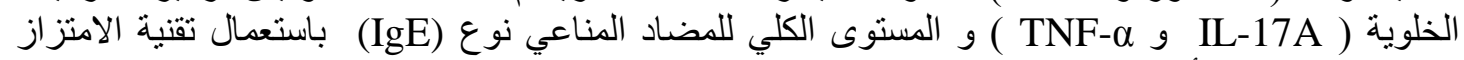

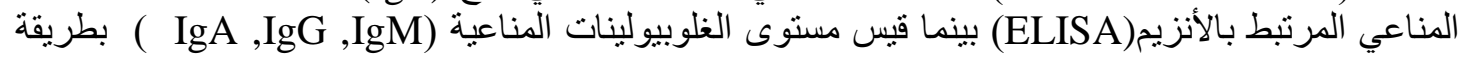

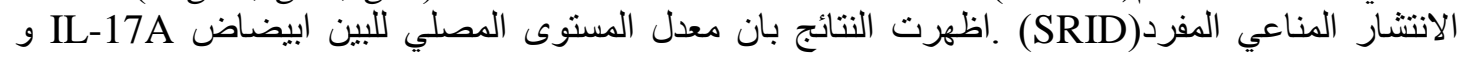

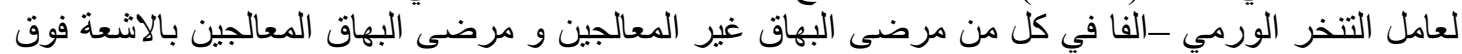

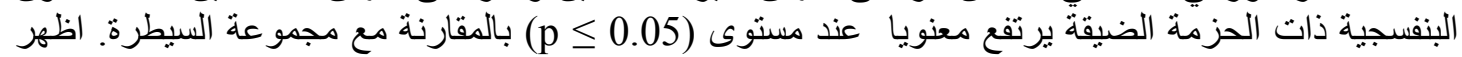

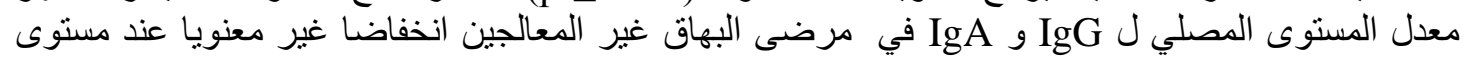

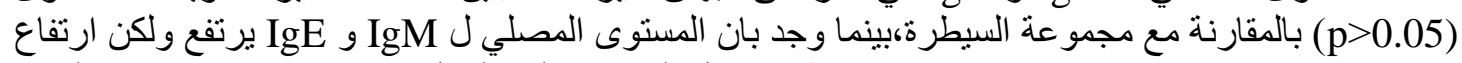

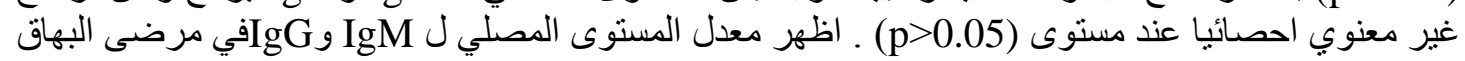

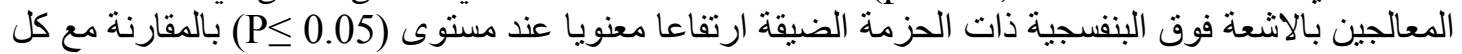

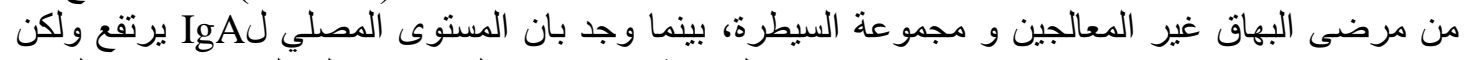

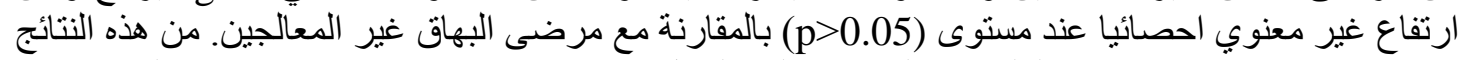

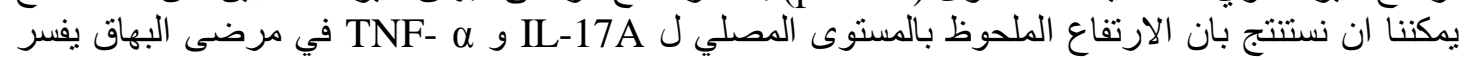

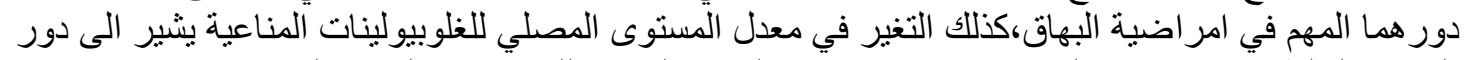

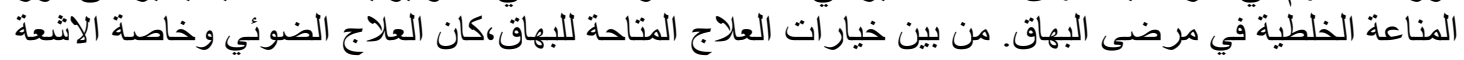

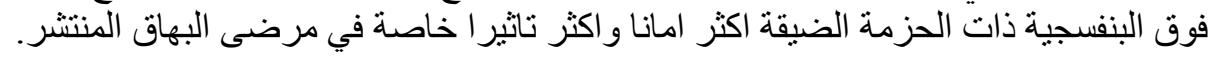
الكلمات المفتاحية : البهاق ، البين ابيضاض IL-17A ، عامل التنخر الورمي- الفا م $\alpha$ ، الغلوبيولينات المناعية. 